\title{
Legal Definitions in English, Hungarian and Polish Statutory Instruments
}

\author{
Karolina Kaczmarek, Aleksandra Matulewska \\ Laboratorium Legilingwistyki, Instytut Językoznawstwa, \\ Uniwersytet im. Adama Mickiewicza \\ ul. Międzychodzka 5, 60-371 Poznań \\ lingua.legis@gmail.com
}

\begin{abstract}
This article is to explain and compare the structure of legal definitions in English, Hungarian and Polish statutory instruments. Legal definitions are a tool enabling to make terms and legal texts more precise and unambiguous. There is a wide array of legal definitions. The following definitions will be discussed in this article: (i) definitions in the form of glossaries, (ii) bracket definitions within clauses, and (iii) non-bracket definitions within clauses. The following types of definitions will be compared: (i) parity definitions (1. classic definitions, 2. limited classic definitions, 3. non-classic definitions and within that category especially incomplete, complete, complete blank and partial definitions, 4. aggregative definitions), (ii) non-parity definitions (1. iconographic definitions and 2. conditional definitions).
\end{abstract}

\section{Introduction}

In this work legal definitions are those which are in statutory texts and which introduce an unknown term with the help of known terms. They are formulated in order to make the statutory text unambiguous and precise. Their task is to enable differentiation between the colloquial and legal meanings of words and syntagmas as well as to give the precise meaning to agents, things or conventional actions created by the legislator (Zieliński 2002:188).

Legal definitions play a very important role in statutory texts. Zieliński (2002:188-191) and Wronkowska, Zieliński (1993:118) give the following functions of legal definitions:

1) creation of agents, things, actions and institutions,

2) limiting or liquidating ambiguities connected with the difference between colloquial and legal languages or choosing one specific meaning of ambiguous terms,

3) making non-precise terms unambiguous,

4) giving the meaning of not widely-known terms from ethnic languages,

5) giving the legal meaning to terms borrowed from the languages for special purposes.

Legal definitions give the meaning of terms used in one act or in other acts related to it. Sometimes definitions are formulated just for the purpose of the specific title or even chapter of a statutory text. The range of definitions depends on their location within legal acts. If the definition is located in general clauses at the beginning of an act then it usually refers to the whole act. Therefore, every time it is repeated, the meaning remains the same. But it may also be located within special or detailed clauses and then the meaning given there usually refers only to the set of those special clauses. There are various classifications of definitions (cf. Doroszewski 1954, Apresjan 1972, Mikołajczyk-Matyja 1998, Seretny 1998). However, for the purpose of this paper 
the legal classification (Zieliński 2002; Wronkowska, Zieliński 1993, Patryas 1997) will be used. It should be born in mind that the legal classification is based on linguistics definition models.

From the strictly technical point of view there are three kinds of legal definitions in statutory texts:

1) definitions in the form of glossaries [definicje w stowniczku] e.g.

\section{Example in Polish:}

Objaśnienie wyrażeń ustawowych

Art. 115. $\S 1$. Czynem zabronionym jest zachowanie o znamionach określonych w ustawie karnej.

$\S 2$. Przy ocenie stopnia społecznej szkodliwości czynu sąd bierze pod uwagę rodzaj i charakter naruszonego dobra, rozmiary wyrządzonej lub grożącej szkody, sposób i okoliczności popełnienia czynu, wagę naruszonych przez sprawcę obowiązków, jak również postać zamiaru, motywację sprawcy, rodzaj naruszonych reguł ostrożności i stopień ich naruszenia.

$\S 3$. Przestępstwami podobnymi są przestępstwa należące do tego samego rodzaju; przestępstwa z zastosowaniem przemocy lub groźby jej użycia albo przestępstwa popełnione w celu osiągnięcia korzyści majątkowej uważa się za przestępstwa podobne.

$\S 4$. Korzyścią majątkową jest korzyść dla:

1) siebie,

2) innej osoby fizycznej lub prawnej,

3) jednostki organizacyjnej nie mającej osobowości prawnej,

4) grupy osób prowadzącej zorganizowaną działalność przestępczą.

$\S 5$. Mieniem znacznej wartości jest mienie, którego wartość w chwili popełnienia czynu zabronionego przekracza dwustukrotną wysokość najniższego miesięcznego wynagrodzenia. $\S 6$. Mieniem wielkiej wartości jest mienie, którego wartość w chwili popełnienia czynu zabronionego przekracza tysiąckrotną wysokość najniższego miesięcznego wynagrodzenia. $\S 7$. Przepisy $\S 5$ i 6 stosuje się do określenia "znaczna szkoda" oraz "szkoda w wielkich rozmiarach".

$\S 8$. Najniższym wynagrodzeniem jest najniższe wynagrodzenie pracowników określone na podstawie Kodeksu pracy.

$\S 9$. Rzeczą ruchomą lub przedmiotem jest także polski albo obcy pieniądz lub inny środek płatniczy oraz dokument uprawniający do otrzymania sumy pieniężnej albo zawierający obowiązek wypłaty kapitału, odsetek, udziału w zyskach albo stwierdzenie uczestnictwa w spółce.

$\S 10$. Młodocianym jest sprawca, który w chwili popełnienia czynu zabronionego nie ukończył 21 lat i w czasie orzekania w pierwszej instancji 24 lat.

$\S 11$. Osobą najbliższą jest małżonek, wstępny, zstępny, rodzeństwo, powinowaty w tej samej linii lub stopniu, osoba pozostająca $\mathrm{w}$ stosunku przysposobienia oraz jej małżonek, a także osoba pozostająca we wspólnym pożyciu.

$\S 12$. Groźbą bezprawną jest zarówno groźba, o której mowa w art. 190, jak i groźba spowodowania postępowania karnego lub rozgłoszenia wiadomości uwłaczającej czci zagrożonego lub jego osoby najbliższej; nie stanowi groźby zapowiedź spowodowania postępowania karnego, jeżeli ma ona jedynie na celu ochronę prawa naruszonego przestępstwem.

$\S 13$. Funkcjonariuszem publicznym jest:

1) Prezydent Rzeczypospolitej Polskiej,

2) posel, senator, radny,

3) (8) sędzia, ławnik, prokurator, notariusz, komornik, kurator sądowy, osoba orzekająca w sprawach o wykroczenia lub w organach dyscyplinarnych działających na podstawie ustawy,

4) osoba będąca pracownikiem administracji rządowej, innego organu państwowego lub samorząau terytorialnego, chyba że pełni wyłącznie czynności usługowe, a także inna osoba w zakresie, w którym uprawniona jest do wydawania decyzji administracyjnych,

5) osoba będąca pracownikiem organu kontroli państwowej lub organu kontroli samorządu terytorialnego, chyba że pełni wyłącznie czynności usługowe,

6) osoba zajmująca kierownicze stanowisko w innej instytucji państwowej,

7) funkcjonariusz organu powołanego do ochrony bezpieczeństwa publicznego albo funkcjonariusz Służby Więziennej,

8) osoba pełniąca czynną służbę wojskową. 
$\S 14$. Dokumentem jest każdy przedmiot lub zapis na komputerowym nośniku informacji, z którym jest związane określone prawo albo który ze względu na zawartą w nim treść stanowi dowód prawa, stosunku prawnego lub okoliczności mającej znaczenie prawne.

$\S 15$. W rozumieniu tego kodeksu za statek wodny uważa się także stałą platformę umieszczoną na szelfie kontynentalnym.

$\S 16$. Stan nietrzeźwości w rozumieniu tego kodeksu zachodzi, gdy:

1) zawartość alkoholu we krwi przekracza 0,5 promila albo prowadzi do stężenia przekraczającego tę wartość lub

2) zawartość alkoholu w $1 \mathrm{dm} 3$ wydychanego powietrza przekracza $0,25 \mathrm{mg}$ albo prowadzi do stężenia przekraczającego tę wartość.

$\S 17$. Żołnierzem jest osoba pełniąca czynną służbę wojskową.

$\S 18$. Rozkazem jest polecenie określonego działania lub zaniechania wydane służbowo żołnierzowi przez przełożonego lub uprawnionego żołnierza starszego stopniem (KK).

\section{Example in English:}

Sec. 311.005. GENERAL DEFINITIONS.1 The following definitions apply unless the statute or context in which the word or phrase is used requires a different definition:

"Oath" includes affirmation.

"Person" includes corporation, organization, government or governmental subdivision or agency, business trust, estate, trust, partnership, association, and any other legal entity.

"Population" means the population shown by the most recent federal decennial census.

"Property" means real and personal property.

"Rule" includes regulation.

"Signed" includes any symbol executed or adopted by a person with present intention to authenticate a writing.

"State," when referring to a part of the United States, includes any state, district, commonwealth, territory, and insular possession of the United States and any area subject to the legislative authority of the United States of America.

"Swear" includes affirm.

"United States" includes a department, bureau, or other agency of the United States of America.

"Week" means seven consecutive days.

"Written" includes any representation of words, letters, symbols, or figures.

"Year" means 12 consecutive months.

"Includes" and "including" are terms of enlargement and not of limitation or exclusive enumeration, and use of the terms does not create a presumption that components not expressed are excluded (US Code Construction Act).

\section{Example in Hungarian:}

2. § A rendeletben alkalmazott egyes fogalmak meghatározását az 1. számú függelék tartalmazza. [...]

1. számú függelék:

I. Az úttal kapcsolatos fogalmak

a) Út: a gyalogosok és a közúti járművek közlekedésére szolgáló közterület (közút), illetőleg magánterület (közforgalom elől el nem zárt magánút).

b) Járda: az útnak a gyalogosok közlekedésére szolgáló - az úttesttől szintkülönbséggel, kiemelt szegéllyel, vagy más látható módon elhatárolt - része; a gyalogút azonban nem járda. c) Úttest: az útnak a közúti jármüvek közlekedésére szolgáló része.

d) A menetirány szerinti jobb oldal: az úttestnek az a része, amely - a menetirányt tekintve - az úttest útburkolati jellel megjelölt vagy képzeletbeli felezővonalától jobb oldalra esik. Egyirányú forgalmú úton és körfogalmú úton az úttest, továbbá osztottpályás úton a menetirányt tekintve jobb oldalra eső úttest teljes szélességében menetirány szerinti jobb oldalnak tekintendő.

e) Forgalmi sáv: az úttestnek egy gépkocsisor biztonságos közlekedésére elegendő szélességü akár útburkolati jellel megjelölt, akár meg nem jelölt - része.

\footnotetext{
${ }^{1}$ Capital letters in the original.
} 
f) Leállósáv: az útnak az úttesttel azonos szintben levő, attól útburkolati jellel elválasztott és útburkolattal ellátott része.

f/1. Kerékpársáv: az úttesten útburkolati jellel kijelölt - kerékpárosok egyirányú közlekedésére szolgáló - különleges forgalmi sáv.

g) Útpadka: az útnak az úttest mellett levő, útburkolattal el nem látott része.

h) Kerékpárút: jelzőtáblával kerékpárútként megjelölt út.

i) Járdasziget: az útnak az úttesten levő, attól kiemelt szegéllyel elválasztott és körülhatárolt - a jármüforgalom elől elzárt, a gyalogosok védelmére vagy a járműforgalom irányítására szolgáló - része.

j) Osztottpályás út: olyan út, amelynek a két forgalmi irány céljára - egymástól járdaszigettel, növényzettel, zárt villamospályával vagy más hasonló módon elválasztott - két külön úttestje van.

k) Útkereszteződés: két vagy több útnak azonos szintben való kereszteződése, egymásba torkollása, illetőleg elágazása.

1) Autópálya: jelzőtáblával autópályaként megjelölt osztottpályás út.

m) Autóút: jelzőtáblával autóútként megjelölt út.

n) Főútvonal: jelzőtáblával fóútvonalként megjelölt út.

o) Gyalogút: jelzőtáblával gyalogútként megjelölt út, illetőleg olyan út, amely kizárólag a gyalogosok közlekedésére szolgál és az úttesttől tartós fizikai akadály (árok, korlát, kerítés, sövény, stb.) vagy két méternél nagyobb távolság választja el.

p) Útzár: a közútnak, rendőrségi ellenőrzés céljából, a jármüvek továbbhaladását akadályozó eszközökkel történő lezárása.

r) Biztosított vasúti átjáró: a közúti járművek forgalmát teljes sorompó; teljes sorompó és piros fényt adó kiegészítő berendezés; hangjelző berendezés; fénysorompó; félsorompóval kiegészített fénysorompó; jelzőőr szabályozza.

s) Biztosítatlan vasúti átjáró: a közúti járművek forgalmát az r) pontban meghatározott berendezések vagy jelzőőr nem szabályozza.

sz) Földút: jármü közlekedésre szabadon tartott, eredeti termett talajú vagy ahhoz hasonló anyagú (pl. zúzottkö, kavics, murva, kohósalak stb.) út, amelyen legfeljebb talajszerkezetet javító beavatkozás történt, ideértve azon földutat is, amely a szilárd burkolatú úthoz való csatlakozás, illetve a vasúti átjáró előtt legfeljebb 50 méter hosszban szilárd burkolattal rendelkezik.

t) Szilárd burkolatú út: olyan út, amelynek úttestje szabályosan lerakott kő vagy műkő, továbbá beton vagy aszfalt burkolattal rendelkezik (1/1975. (II. 5.) KPM-BM rendelet a közúti közlekedés szabályairól).

2) bracket definitions within clauses [definicje nawiasowe],

\section{Examples in English:}

Those who may propose an arrangement

(2) A proposal under this part is one which provides for some person ("the nominee") to act in relation to the voluntary arrangement either as a trustee or otherwise for the purpose of supervising its implementation (...). [Insolvency Act 1986 (Great Britain)]

8. (2) An administration order is an order directing that, during the period for which the order is in force, the affairs, business and property of the company shall be managed by a person ("the administrator") appointed for the purpose by the court (Insolvency Act 1986).

\section{Examples in Polish:}

Art. 86. $§ 1$. Spółką partnerską jest spółka osobowa, utworzona przez wspólników (partnerów) w celu wykonywania wolnego zawodu w spółce prowadzącej przedsiębiorstwo pod własną firmą. $(\mathrm{KH})$

Art. 102. Spółką komandytową jest spółka osobowa mająca na celu prowadzenie przedsiębiorstwa pod własną firmą, w której wobec wierzycieli za zobowiązania spółki co najmniej jeden wspólnik odpowiada bez ograniczenia (komplementariusz), a odpowiedzialność co najmniej jednego wspólnika (komandytariusza) jest ograniczona (KC). 


\section{Example in Hungarian:}

(2) E törvény alkalmazásában

1. anyavállalat: az a vállalkozó, amely egy másik vállalkozónál (a továbbiakban: leányvállalat) közvetlenül vagy leányvállalatán keresztül közvetetten meghatározó befolyást képes gyakorolni, mert az alábbi feltételek közül legalább eggyel rendelkezik:

a) a tulajdonosok (a részvényesek) szavazatának többségével (50 százalékot meghaladóval) tulajdoni hányada alapján egyedül rendelkezik, vagy

b) más tulajdonosokkal (részvényesekkel) kötött megállapodás alapján a szavazatok többségét egyedül birtokolja, vagy

c) a társaság tulajdonosaként (részvényeseként) jogosult arra, hogy a vezető tisztségviselők vagy a felügyelö bizottság tagjai többségét megválassza vagy visszahívja, vagy

d) a tulajdonosokkal (a részvényesekkel) kötött szerződés (vagy a létesítő okirat rendelkezése) alapján - függetlenül a tulajdoni hányadtól, a szavazati aránytól, a megválasztási és visszahívási jogtól - döntő irányítást, ellenőrzést gyakorol (2000. évi C.törvény a számvitelről).

3) non-bracket definitions within clauses [definicje $w$ wydzielonych/oddzielnych przepisach].

\section{Example in Polish:}

Art. 5. 1. Przepisy ustawy stosuje się do dłużników będących przedsiębiorcami, jeżeli ustawa nie stanowi inaczej.

2. "Przedsiębiorcą" w rozumieniu ustawy jest osoba fizyczna, osoba prawna albo jednostka organizacyjna nieposiadająca osobowości prawnej, której odrębna ustawa przyznaje zdolność prawną, prowadząca we własnym imieniu działalność gospodarczą lub zawodową (PUIN).

\section{Examples in English:}

Art. 646.A predial servitude is a charge on a servient estate for the benefit of a dominant estate. (...) (LCC)29. (2) In This Chapter "administrative receiver" means (...) (Insolvency Act 1986).

\section{Examples in Hungarian:}

2. § (1) A cég - ha törvény eltérően nem rendelkezik - az a jogalany, amely a cégnyilvántartásba történő bejegyzéssel, üzletszerủ gazdasági tevékenység folytatása céljából jön létre. (2006. évi V. törvény a cégnyilvánosságról, a bírósági cégeljárásról és a végelszámolásról).

18. § E törvény alkalmazásában szakszervezeten a munkavállalóknak minden olyan szervezetét érteni kell, amelynek elsődleges célja a munkavállalók munkaviszonnyal kapcsolatos érdekeinek előmozdítása és megvédése (1992. évi XXII. törvény a Munka Törvénykönyvéről).

As this paper deals with the legal language the location of a definition within the statutory texts is of less, while its structure and types is of more interest.

\section{The Structure of Definitions}

Definitions usually consist of the following elements (Patryas 1997):

1) definiendum - a term which is to be defined [wyrażenie definiowane, zwrot definiowany, definiendum], which comprises one or more words,

2) definiens - the word or words used to define the meaning of a definiendum [zwrot definiujacy, definiens],

3) linking expression or word - which links a definiendum with its definiens [tacznik].

Each definition has a definiendum and a definiens but not necessarily a linking word or expression.

A wide array of linking expressions and words is exemplified by statutory definitions presented below (Table 1). 
Table 1: Linking expressions in statutory definitions

\begin{tabular}{|c|c|c|}
\hline$\overline{\text { POLISH }}$ & ENGLISH & HUNGARIAN \\
\hline $\begin{array}{l}\text {...jest to... } \\
\text {...są to... } \\
\text {...jest, kto... } \\
\text {...jest... } \\
\text {...są... } \\
\text {...to... } \\
\text {...oznacza... } \\
\text {...oznaczają... } \\
\text { przez...rozumie się... } \\
\text {...rozumie się przez to... } \\
\text { za ... uważa się... } \\
\text {...określa... } \\
\text {...jest nazywane.. } \\
\text {...odnosi się do... }\end{array}$ & $\begin{array}{l}\ldots \text {. is called... } \\
\ldots \text {..means... } \\
\ldots \text {. is... } \\
\ldots \text {.re... } \\
\ldots \text { is that... } \\
\ldots \text {. includes... } \\
\ldots \text {.refers to... } \\
\ldots \text {. is referred to as... }\end{array}$ & $\begin{array}{l}\text {...(erdőnek) kell tekinteni... } \\
\text {...(erdőgazdálkodásnak) } \\
\text { minősül... } \\
\text { Nem minősül (adózónak)... } \\
\text {...(a munkavállalóknak } \\
\text { minden olyan szervezetét) } \\
\text { érteni kell... }\end{array}$ \\
\hline
\end{tabular}

\section{Examples in Polish:}

Art. 113. $\S 1$. Jeżeli termin jest oznaczony na początek, środek lub koniec miesiąca, rozumie się przez to pierwszy, piętnasty lub ostatni dzień miesiąca.

$\S 2$. Termin półmiesięczny jest równy piętnastu dniom (KC).

Art. 85. 2. Przez terminowe operacje finansowe, o których mowa w ust. 1, rozumie się operacje, w których ustalono cenę, kurs, stopę procentową lub indeks - a w szczególności nabywanie walut, papierów wartościowych, złota lub innych metali szlachetnych, towarów lub praw, w tym umowy obliczone tylko na różnicę cen, opcje i prawa pochodne - zawarte na umówioną datę lub umówiony termin, w obrocie rynkowym. (PUIN)

Art. 50. Za części składowe nieruchomości uważa się także prawa związane z jej własnością (KC).

Art. 44. ${ }^{2}$ Mieniem jest własność $\mathrm{i}$ inne prawa majątkowe (KC).

Art. 10. § 1. Pełnoletnim jest, kto ukończył lat osiemnaście (KC).

Art. 45. Rzeczami w rozumieniu niniejszego kodeksu są tylko przedmioty materialne (KC). Art. $\mathbf{4 6}^{1}$. Nieruchomościami rolnymi (gruntami rolnymi) są nieruchomości, które są lub mogą być wykorzystywane do prowadzenia działalności wytwórczej w rolnictwie $\mathrm{w}$ zakresie produkcji roślinnej i zwierzęcej, nie wyłączając produkcji ogrodniczej, sadowniczej i rybnej. Art. 482. Użyte w art. 481 określenia oznaczają:

"krajowy zakład ubezpieczeń" - przedsiębiorcę mającego siedzibę na terenie Rzeczypospolitej Polskiej, który uzyskał zezwolenie na wykonywanie działalności ubezpieczeniowej w rozumieniu odrębnych przepisów; (PUIN).

Art. 379. Ilekroć w przepisach niniejszej części mowa jest o:

"zagranicznym postępowaniu upadłościowym" - oznacza to wszelkie prowadzone za granicą postępowania sądowe lub administracyjne, których przedmiotem jest wspólne dochodzenie roszczeń, nawet jeśli mają charakter tymczasowy, przeciwko niewypłacalnemu dłużnikowi, w których mienie i sprawy dłużnika są poddane kontroli lub zarządowi zagranicznego sądu w celu ich restrukturyzacji lub likwidacji; (PUIN).

\section{Examples in English:}

Art. 871

Succession is the transmission of the estate of the deceased to his successors. (...) (LCC). Art. 38 .

The domicile of each citizen is in the parish wherein he has his principal establishment.

The principal establishment is that in which he makes his habitual residence (...) (LCC).

\footnotetext{
${ }^{2}$ http://bap-student.lex.pl/cgi-bin/demo.cgi?id=\&comm=przypis\&akt=16785996\&ver=39\&nr=13
} 


\section{Art. 872 .}

The estate of a deceased means the property, rights, and obligations that a person leaves after his death, whether the property exceeds the charges or the charges exceed the property or whether he has only left charges without any property. The estate includes not only the right and obligations of the deceased as they exist at the time of death but all that has accrued thereto since death, and the new charges to which it becomes subject (LCC).

1. Those who may propose an arrangement

(1) The directors of the company (...) may take a proposal under this Part to the company and to its creditors for a composition in satisfaction of its debts or a scheme nor arrangement of its affairs (from here on referred to, in either case, as a "voluntary arrangement") (Insolvency Act 1986).

Art. 1095.

A succession is called vacant when no one claims it, or when all the heirs are unknown, or all the known heirs to it have renounced it (LCC).

Art.499. Alluvion and dereliction

Accretion formed successively and imperceptibly on the bank of a river or stream, whether navigable or not, is called alluvion (LCC).

84. (2) In this Act the expression "a resolution for voluntary winding up" means a resolution passes under of the paragraphs of subsection (1) (Insolvency Act 1986).

\section{Examples in Hungarian:}

18. § E törvény alkalmazásában szakszervezeten a munkavállalóknak minden olyan szervezetét érteni kell, amelynek elsődleges célja a munkavállalók munkaviszonnyal kapcsolatos érdekeinek előmozdítása és megvédése. (1992. évi XXII. törvény a Munka Törvénykönyvéröl) 12. Rendszeresen végzett képzésnek minősül a folyamatosan nyújtott, illetve az egy éven belül ismétlődően biztosított képzés. (2001. évi CI. Törvény a felnőttképzésről)

(8) A (7) bekezdés szerinti határidő lejártának kiszámításakor a jogsértő esemény bekövetkezésének kell tekinteni

a) jogellenes tartalmú felhívás, illetőleg dokumentáció esetén az ajánlattételi, illetve részvételi jelentkezési határidő lejártát;

b) az előirt határidőnél később közzétett hirdetmény esetén a hirdetmény megjelenését;

c) közbeszerzési eljárás mellőzésével történő beszerzés esetén a szerződés megkötését (1999. évi LX. Törvény a közbeszerzésekről szóló 1995. évi XL. törvény módosításáról).

Table 2: The most often used linking words and expressions in statutory definitions

\begin{tabular}{|l|l|l|}
\hline \multicolumn{1}{|c|}{ POLISH } & \multicolumn{1}{c|}{ ENGLISH } \\
$\ldots$..jest... & $\ldots$ is called... & $\ldots$ kell tekinteni... \\
$\ldots$..oznacza... & $\ldots$ means... & $\ldots$ minösül... \\
$\ldots$..oznaczają... & $\ldots$ is ... & $\ldots$ érteni kell... \\
przez...rozumie się... & $\ldots$ are... \\
$\ldots$..rozumie się przez to... & $\ldots$ is referred to as... & \\
za ... uważa się... & & \\
& & \\
\hline
\end{tabular}

\section{Types of Legal Definitions}

The following types of definitions in statutory texts can be distinguished:

1) parity definitions [definicje równościowe]

In those definitions definiens and definiendum are in a relation of parity which means that the meanings of definiens and definiendum are exactly the same.

Table 3: The most often used linking words and expressions in parity definitions

\begin{tabular}{|l|l|l|}
\hline \multicolumn{1}{|c|}{ POLISH } & \multicolumn{1}{c|}{ ENGLISH } & HUNGARIAN \\
\hline ...jest (wyłącznie/jedynie)..., & $\begin{array}{l}\text {...is..., } \\
\text {...ara (wyłącznie/jedynie)...; }\end{array}$ & \\
\hline
\end{tabular}


(i) classical definitions [definicje klasyczne]

A definiens explains the meaning of a definiendum by using an expression which has a wider meaning than that of the definiendum. In order to make this definition more precise there are some additional qualities, which are characteristic only of the definiendum, added to it. The most common linking words and expressions used in them are gathered in Table 4.

Table 4: The most often used linking words and expressions in classical definitions

\begin{tabular}{|l|l|l|}
\hline \multicolumn{1}{|c|}{ POLISH } & \multicolumn{1}{c|}{ ENGLISH } \\
\hline$\ldots$ Hest... & ...is... & - \\
$\ldots$... $\mathrm{sa} . .$. & ..are... & \\
\hline
\end{tabular}

\section{Examples in Polish:}

Art. 102. Spółką komandytową jest spółka osobowa mająca na celu prowadzenie przedsiębiorstwa pod własną firmą, w której wobec wierzycieli za zobowiązania spółki co najmniej jeden wspólnik odpowiada bez ograniczenia (komplementariusz), a odpowiedzialność co najmniej jednego wspólnika (komandytariusza) jest ograniczona (KH). Art. 26. 1. Uczestnikiem postępowania o ogłoszenie upadłości jest każdy, kto złożył wniosek o ogłoszenie upadłości, oraz dłużnik (PUIN).

\section{Examples in English:}

Art. 86.

Marriage is a legal relationship between a man and a woman that is created by civil contract. (...) (LCC).

Art. 451. Seashore

Seashore is the space of land over which the waters of the sea spread in the highest tide during the winter season (LCC).

Art. 646. Predial servitude; definition

A predial servitude is a charge on a servient estate for the benefit of a dominant estate.

The two estates must belong to different owners (LCC).

In Hungarian there is a nominal sentence (Benkö, Samu Imre 1972:86) without the auxiliary verb van. That is why in an equivalent Hungarian definition parallel to Polish and English ones there is no verb van (be) in the place where in a Polish sentence there is verb jest or sa, and in an English sentence verb is or are. In the following examples the place in which there would be verb be in English and Polish sentences is marked with $\underline{\mathrm{xxx}}$ to illustrate the problem.

\section{Examples in Hungarian:}

6. § (1) Adózó Xxx az a személy, akinek adókötelezettségét, adófizetési kötelezettségét, adót, költségvetési támogatást megállapító törvény vagy e törvény írja elö (2003. évi XCII. Törvény az adózás rendjéről).

21. § A Btk. alkalmazásában szövetkezet $\underline{x x x}$ a szövetkezeti vállalat, valamint a kizárólag szövetkezetek részvételével müködő, jogi személyiséggel rendelkező gazdasági társulás is.(1979. évi 5. törvényerejü rendelet a Büntető Törvénykönyvről szóló 1978. évi IV. törvény hatálybalépéséről és végrehajtásáról).

(ii) limited classical definitions [definicje klasyczne ograniczone]

Those definitions give the meaning which is only applied to a certain group of provisions or to a certain act. The most commonly used linking words in this type of definitions may be found in Table 5. 
Table 5: The most often used linking words and expressions in limited classical definitions

\begin{tabular}{|c|c|c|}
\hline POLISH & ENGLISH & HUNGARIAN \\
\hline $\begin{array}{l}\ldots \text {..W rozumieniu niniejszego } \\
\text { kodeksu są... } \\
\ldots \text { w rozumieniu niniejszego } \\
\text { rozdziału są... } \\
\text { ilekroć w przepisach niniejszej } \\
\text { części mowa jest o...oznacza to ... }\end{array}$ & $\begin{array}{l}\text { In this section } \\
\text { (the expression)...means... } \\
\text { In this chapter } \\
\text { (the expression)... means.... }\end{array}$ & $\begin{array}{l}\text { Az (1) bekezdés } \\
\text { alkalmazásában... } \\
\text { E törvény alkalmazásában:... } \\
\text { E törvény alkalmazása során... } \\
\text { E törvény alkalmazásában az } \\
\text { egyes fogalmak jelentése a } \\
\text { következő:... }\end{array}$ \\
\hline
\end{tabular}

\section{Examples in Polish:}

Art. 45. Rzeczami w rozumieniu niniejszego kodeksu są tylko przedmioty materialne.

Art. 379. Ilekroć w przepisach niniejszej części mowa jest o:

"zagranicznym postępowaniu upadłościowym" - oznacza to wszelkie prowadzone za granicą postępowania sądowe lub administracyjne, których przedmiotem jest wspólne dochodzenie roszczeń, nawet jeśli mają charakter tymczasowy, przeciwko niewypłacalnemu dłużnikowi, w których mienie i sprawy dłużnika są poddane kontroli lub zarządowi zagranicznego sądu w celu ich restrukturyzacji lub likwidacji; (PUIN).

\section{Examples in English:}

84. (2) In this Act the expression "a resolution for voluntary winding up" means a resolution passes under of the paragraphs of subsection (1) (Insolvency Act 1986).

95. (7) In this section "the relevant period" means the period of 6 months immediately preceding the day on which were sent the notices summoning the company meeting at which it was resolved that the company be wound up voluntarily (Insolvency Act 1986).

\section{Example in Hungarian:}

4. § E törvény alkalmazásában: a) természeti érték: a természeti erőforrás [Kt. 4 . § c) pont], az élővilág és a fennmaradásához szükséges élettelen környezete, valamint más - e törvényben meghatározott -, természeti erőforrásnak nem minősülő környezeti elem (1996. ÉVI LIII. törvény a természet védelméről).

\section{3. § E törvény alkalmazásában az egyes fogalmak jelentése a következö:}

1.Belföld: a Magyar Köztársaság területe, beleértve a vámszabadterületet is (1991. évi XC. törvény

a magánszemélyek jövedelemadójáról).

\section{3. § E törvény alkalmazása során}

a) szerv: a jogi személy és a jogi személyiséggel nem rendelkező szervezet (1995. évi LXVI. törvény a közokiratokról, a közlevéltárakról és a magánlevéltári anyag védelméről).

(iii) non-classical definitions [definicje nieklasyczne]

A definiens is an enumeration of terms the meaning of which creates the meaning of a definiendum.
a) incomplete definitions [definicje niepetne]

The enumeration of terms which create a definiens is not exhaustive. The words and expressions which usually characterize that type of definitions may be found in Table 6 .

Table 6: The most often used linking words and expressions in incomplete definitions

\begin{tabular}{|c|c|c|}
\hline POLISH & ENGLISH & HUNGARIAN \\
\hline $\begin{array}{l}\text {...rozumie się również... } \\
\text {...należy przez to rozumieć także... } \\
\text {...należy przez to również rozumieć... } \\
\text {...rozumie się także... } \\
\text {...jest również... } \\
\text {...uważa się również... } \\
\text {...W szczególności... } \\
\text {...i inne... }\end{array}$ & $\begin{array}{l}. . \text { is such as.. } \\
\ldots \text { are such as.. } \\
\ldots \text { and other... } \\
\ldots \text {.includes... } \\
\ldots \text { this includes... } \\
\text { The following are } \\
\text { examples of ... }\end{array}$ & ....alatt (az eurót) is érteni kell. \\
\hline
\end{tabular}




\section{Examples in Polish:}

Art. 44. Mieniem jest własność i inne prawa majątkowe (KC).

Art. 4. Ilekroć w ustawie mowa jest o "umowie spółki", należy przez to rozumieć także akt założycielski sporządzony przez jedynego wspólnika albo akcjonariusza spółki kapitałowej (KH).

\section{Examples in English}

Art.449. Common things

Common things (...) are such as the air and the high seas that may be freely used by everyone comfortably with the use for which nature has intended them (LCC).

Art. 463. Component parts of tracts of land

Buildings, other constructions permanently attached to the ground, standing timber, and unharvested crops or ungathered fruits of trees, are component parts of tracts of land when they belong to the owner of the ground (LCC).

Art. 699 Examples of predial servitudes

The following are examples of predial servitudes:

Rights of support, projection, drip, drain, or of preventing drain, those of view, of light, or of preventing view or light from being obstructed, of raising buildings or walls, or of preventing them from being raised, of passage, of drawing water, of aqueduct, of watering animals, and of pasturage (LCC).

Art. 701. Servitude of view

The servitude of view is the right by which the owner of the dominant estate enjoys a view; this includes the right to prevent the raising of constructions on the servient estate that would obstruct the view (LCC).

\section{Examples in Hungarian:}

(3) A külföldi pénz, illetve értékpapír a belföldiével azonos védelemben részesül. Külföldi pénz alatt az eurót is érteni kell.

(4) A Btk. 304-306. §-ának alkalmazása szempontjából pénz alatt a forgalomból kivont bankjegyet és érmét is érteni kell, ha annak törvényes fizetőeszközre történő beváltására a kivont bankjegyet, illetve érmét kibocsátó állam nemzeti bankja jogszabály alapján köteles, vagy arra kötelezettséget vállalt (1979. évi 5. törvényerejü rendelet a Büntető Törvénykönyvröl szóló 1978. évi IV. törvény hatálybalépéséröl és végrehajtásáról).

b) complete definitions [definicje petne]

Definiens is comprised of the exhaustive list of terms forming the meaning of definiendum. The words and expressions which usually characterize that type of definitions may be found in Table 7.

Table 7: The most often used linking words and expressions in complete definitions

\begin{tabular}{|l|l|l|}
\hline \multicolumn{2}{|c|}{ POLISH } & \multicolumn{1}{|c|}{ ENGLISH } \\
\hline ...ą.... & There are ... kinds of...........are.... & - \\
\hline
\end{tabular}

\section{Example in Polish:}

Art. 1. (...)

§ 2. Spółkami handlowymi są: spółka jawna, spółka partnerska, spółka komandytowa, spółka komandytowo-akcyjna, spółka z ograniczoną odpowiedzialnością i spółka akcyjna $(\mathrm{KH})$.

\section{Example in English:}

Art. 551. Kinds of fruits.

There are two kinds of fruits; natural fruits and civil fruits.

Natural fruits are products of the earth or of animals. (...) (LCC).

\section{Example in Hungarian:}

10. § E törvény alkalmazásában

r) központi adóhatóság: az Adó- és Pénzügyi Ellenőrzési Hivatal és szervei, valamint a Vám-

és Pénzügyörség Országos Parancsnoksága és szervei (Közbeszerzési törvény). 
c) Blank complete definitions [definicja petna blankietowa]

A definiens comprises the exhaustive list of terms constituting the meaning of a definiendum. However, the definiens is not specific as it contains reference to other provisions in which there are given other elements of the enumeration. The words and expressions which usually characterize this kind of definitions may be found in Table 8 .

Table 8: The most often used linking words and expressions in blank complete definitions

\begin{tabular}{|c|c|c|}
\hline POLISH & ENGLISH & HUNGARIAN \\
\hline $\begin{array}{l}\text {...którym przepisy szczególne } \\
\text { przyznają ... } \\
\text {...inne...określone przez } \\
\text { ustawę... }\end{array}$ & $\begin{array}{l}\text {... within the meaning of ... } \\
\text {...such other....as the law } \\
\text { allows. } \\
\text { (... such other... which are) ... } \\
\text { by reason of the juridical act... } \\
\text {...by regulations made by } \\
\text { statutory instrument by the } \\
\text { Secretary of State. }\end{array}$ & $\begin{array}{l}\text { A } 2 . \S \text { a), h) és i) pontjában } \\
\text { meghatározott... } \\
\text { a } 2 . \S(3) \text { bekezdése szerinti... } \\
\text {...az olyan ..., melyet törvény, } \\
\text { kormányrendelet vagy } \\
\text { önkormányzati rendelet } \\
\text {...nak minősít. }\end{array}$ \\
\hline
\end{tabular}

\section{Example in Polish:}

Art. 33. Osobami prawnymi są Skarb Państwa i jednostki organizacyjne, którym przepisy szczególne przyznają osobowość prawną (KC).

\section{Examples in English:}

Art. 476. Rights in things

One may have various rights in things:

Ownership;

Personal and predial servitudes; and

Such other real rights as the law allows (LCC).

Art.551. Kinds of fruits

(...) Civil fruits are revenues derived from a thing by operation of law or by reason of a juridical act, such as rentals, interest, and certain corporate distributions (LCC).

70 (1) (...) "fixed security", in relation to any property of a company, means any security, other than a floating charge, which on the winding up of the company in Scotland would be treated as an effective security over that property (without prejudice to that generality) includes a security over that property, being a heritable security within the meaning of the conveyancing and Feudal Reform (Scotland) Act 1970; (...) (Insolvency Act 1986).

70. (1) In this chapter (...) "prescribed" means prescribed by regulations made under this Chapter by the Secretary of State (Insolvency Act 1986).

\section{Examples in Hungarian:}

8. Fogyatékkal élő felnőtt: a fogyatékos személyek jogairól és esélyegyenlőségük biztosításáról szóló 1998. évi XXVI. törvény 4. § a) pontjában meghatározott fogyatékos személy, amennyiben e törvény alkalmazásában felnőttnek minősül (2001. évi CI. Törvény a felnőttképzésrőll).

10. $\S$ E törvény alkalmazásában

d)támogatás: egy vagy több - az 1. § a), h) és i) pontjában meghatározott - szervezet, illetőleg nemzetközi szervezet által pénzforrás juttatása útján biztosított anyagi előny, melyet a 2. § (1) bekezdésében meghatározott beszerzésre kell fordítani, feltéve, hogy annak (azoknak) az összege meghaladja a beszerzés értékének ötven százalékát és a 2 . § (3) bekezdése szerinti értékhatárt, és a támogatók között legalább egy, az 1. § a), h) és i) pontjában meghatározott szervezet van;

e) közszolgáltató tevékenység: az olyan tevékenység, melyet törvény, kormányrendelet vagy önkormányzati rendelet közszolgáltatásnak, közcélú szolgáltatásnak, közüzemi tevékenységnek, közmü- vagy kommunális szolgáltatásnak minősít (Közbeszerzési törvény). 
d) partial definition [definicja czastkowa]

In this type of a definition the meaning of a definiendum is always equal with that expressed by the definiens, but the meaning of the definiens is not always equal with that of the definiendum as the meaning of the definiens is usually broader than the meaning of the definiendum.

Table 9: The most often used linking words and expressions in partial definitions

\begin{tabular}{|l|l|l|}
\hline \multicolumn{1}{|c|}{ POLISH } & \multicolumn{1}{c|}{ HUNGARIAN } \\
\hline$\ldots$..jest... & $\begin{array}{l}\text {...is... } \\
\text {...are... }\end{array}$ & is rendelkezhet \\
\hline
\end{tabular}

\section{Example in Polish:}

Art. 471. 1. Wniosek o ogłoszenie upadłości zakładu ubezpieczeń może zgłosić także Komisja Nadzoru Ubezpieczeń i Funduszy Emerytalnych, zwana dalej "Komisją".

Komisja jest uczestnikiem postępowania (PUIN).

\section{Example in Hungarian:}

(6) A kinevezési okmánynak tartalmaznia kell a köztisztviselő besorolásának alapjául szolgáló besorolási osztályt, besorolási és fizetési fokozatot, illetményét, annak a besorolása szerinti alapilletményéhez viszonyított beállási szintjét, továbbá a munkakörét és meghatározott feladatkörét, a munkavégzés helyét, az elömenetelhez elöírt kötelezettségeket.

A kinevezési okmány a közszolgálati jogviszonyt érintő egyéb kérdésekről is rendelkezhet (1992. évi XXIII. törvény a köztisztviselők jogállásáról).

(iv) aggregative definitions [definicje agregatowe]

Aggregative definitions are a set of definitions which form one sentence and one definition is separated from the other by a comma or a semicolon.

\section{Example in Polish:}

Art. 4. § 1. Użyte w ustawie określenia oznaczają:

1) spółka osobowa - spółkę jawną, spółkę partnerską, spółkę komandytową i spółkę komandytowo-akcyjną,

2) spółka kapitałowa - spółkę z ograniczoną odpowiedzialnością i spółkę akcyjną,

3) spółka jednoosobowa - spółkę kapitałową, której wszystkie udziały albo akcje należą do jednego wspólnika albo akcjonariusza,

4) spółka dominująca - spółkę handlową w przypadku, gdy:

a) dysponuje bezpośrednio lub pośrednio większością głosów na zgromadzeniu wspólników albo na walnym zgromadzeniu, także jako zastawnik albo użytkownik, bądź w zarządzie innej spółki kapitałowej (spółki zależnej), także na podstawie porozumień z innymi osobami, lub b) jest uprawniona do powoływania lub odwoływania większości członków zarządu innej spółki kapitałowej (spółki zależnej) albo spółdzielni (spółdzielni zależnej), także na podstawie porozumień z innymi osobami, lub

c) jest uprawniona do powoływania lub odwoływania większości członków rady nadzorczej innej spółki kapitałowej (spółki zależnej) albo spółdzielni (spółdzielni zależnej), także na podstawie porozumień $\mathrm{z}$ innymi osobami, lub

d) więcej niż połowa członków zarządu spółki kapitałowej jest jednocześnie członkami zarządu spółki zależnej albo spółdzielni zależnej, lub

e) dysponuje bezpośrednio lub pośrednio większością głosów w spółce osobowej zależnej albo na walnym zgromadzeniu spółdzielni zależnej, także na podstawie porozumień z innymi osobami, lub

f) wywiera decydujący wpływ na działalność spółki kapitałowej zależnej albo spółdzielni zależnej, w szczególności na podstawie umów określonych w art. 7,

5) spółka powiązana - spółkę kapitałową, w której inna spółka handlowa albo spółdzielnia dysponuje bezpośrednio lub pośrednio co najmniej $20 \%$ głosów na zgromadzeniu wspólników albo na walnym zgromadzeniu, także jako zastawnik lub użytkownik, albo na podstawie porozumień z innymi osobami lub która posiada bezpośrednio co najmniej $20 \%$ udziałów albo akcji w innej spółce kapitałowej, 
6) spółka publiczna - spółkę w rozumieniu przepisów o publicznym obrocie papierami wartościowymi,

7) instytucja finansowa - bank, fundusz inwestycyjny, towarzystwo funduszy inwestycyjnych lub powierniczych, narodowy fundusz inwestycyjny, zakład ubezpieczeń, fundusz powierniczy, towarzystwo emerytalne, fundusz emerytalny lub dom maklerski, mające siedzibę w Rzeczypospolitej Polskiej albo w państwie należącym do Organizacji Współpracy Gospodarczej i Rozwoju (OECD),

8) rejestr - rejestr przedsiębiorców,

9) głosy - głosy "za", "przeciw" lub "wstrzymujące się" oddane podczas głosowania w sposób zgodny z ustawą, umową albo statutem spółki,

10) bezwzględna większość głosów - więcej niż połowę głosów oddanych,

11) sprawozdanie finansowe - sprawozdania finansowe w rozumieniu przepisów o rachunkowości.

$\S$ 2. Ilekroć w ustawie mowa jest o "umowie spółki", należy przez to rozumieć także akt założycielski sporządzony przez jedynego wspólnika albo akcjonariusza spółki kapitałowej (KH).

\section{Example in English:}

70. Interpretation for Chapter II

(1) In this Chapter, unless the contrary intention appears, the following expressions have the following meanings respectively assigned to them -

"company" means an incorporated company (whether or not a company within the meaning of the Companies Act) which the Court of Session has jurisdiction to wind up;

"fixed security", in relation to any property of a company, means any security, other than a floating charge, which on the winding up of the company in Scotland would be treated as an effective security over that property (without prejudice to that generality) includes a security over that property, being a heritable security within the meaning of the conveyancing and Feudal Reform (Scotland) Act 1970;

"instrument of appointment" has the meaning given by section 53(1);

"prescribed" means prescribed by regulations made under this Chapter by the Secretary of State;

"receiver" means a receiver of such part of the property of the company as is subject to the floating charge by virtue of which he has been appointed under section 51;

"register of charges" means the register kept by the registrar of companies for the purposes of Chapter II of Part XII of the Companies Act;

"secured debenture" means a bond, debenture, debenture stock or other security which, either itself or by reference to any other instrument, creates a floating charge over all or any part of the property of the company, but does not include a security which creates no charge other than a fixed security; and

"series of secured debentures" means two or more secured debentures created as a series by the company in such a manner that the holders thereof are entitled pari passu to the benefit of the floating charge (Insolvency Act 1986).

\section{Examples in Hungarian:}

E szöveg alkalmazásában

(i) Hágai Megállapodás: az ipari minták nemzetközi letétbe helyezéséről szóló Hágai Megállapodás, amelynek új elnevezése a továbbiakban az ipari minták nemzetközi lajstromozásáról szóló Hágai Megállapodás;

(ii) e szöveg: az e szöveggel létrehozott Hágai Megállapodás;

(iii) Végrehajtási Szabályzat: az e szöveghez kapcsolódó Végrehajtási Szabályzat;

(iv) elöírt: a Végrehajtási Szabályzatban elöírt;

(v) Párizsi Egyezmény: az ipari tulajdon oltalmára 1883. március 20-án, Párizsban létesült Párizsi Egyezmény felülvizsgált és módosított szövege;

(vi) nemzetközi lajstromozás: az ipari minták nemzetközi lajstromozása e szöveg alapján;

(vii) nemzetközi bejelentés: a nemzetközi lajstromozásra irányuló bejelentés;

(viii) nemzetközi lajstrom: a nemzetközi lajstromozásokra vonatkozó olyan adatoknak a Nemzetközi Iroda által fenntartott hivatalos gyüjteménye, amelyek bejegyzését e szöveg vagy a Végrehajtási Szabályzat írja elő vagy teszi lehetővé, függetlenül a hordozótól, amelyen ezeket az adatokat tárolják;

(ix) személy: a természetes és a jogi személy; 
(x) bejelentő: az a személy, akinek a nevében a nemzetközi bejelentést megtették;

(xi) jogosult: az a személy, akinek a javára a nemzetközi lajstromozást a nemzetközi lajstromba bejegyzik;

(xii) kormányközi szervezet: az a kormányközi szervezet, amely a 27. Cikk (1) bekezdésének (ii) pontja alapján e szöveg részesévé válhat;

(xiii) Szerződő Fél: az az állam vagy kormányközi szervezet, amely részese e szövegnek; (xiv) bejelentő szerinti Szerződő Fél: az a Szerződő Fél vagy a Szerződő Felek egyike, amelytől a bejelentő nemzetközi bejelentéshez való jogosultsága származik annak révén, hogy e Szerződő Fél tekintetében a 3. Cikkben meghatározott feltételek legalább egyikét kielégíti; ha a bejelentő nemzetközi bejelentéshez való jogosultsága a 3. Cikk alapján kettő vagy több Szerződő Féltől származhat, a "bejelentő szerinti Szerződő Fél" az, amelyet a nemzetközi bejelentésben ilyenként megjelöltek;

(xv) a Szerződő Fél területe: ha a Szerződő Fél állam, ennek az államnak a területe, ha pedig a Szerződő Fél kormányközi szervezet, az a terület, amelyen az e kormányközi szervezetet létrehozó szerződés alkalmazandó;

(xvi) hivatal: az az intézmény, amelyet a Szerződő Fél hatáskörrel ruházott fel arra, hogy a területére kiterjedő hatállyal ipari mintaoltalmat adjon;

(xvii) vizsgáló hivatal: az a hivatal, amely hivatalból vizsgálja az ipari mintaoltalmi bejelentéseket, legalább annak megállapítása céljából, hogy az ipari minta megfelel-e az újdonság követelményének;

(xviii) megjelölés: az arra irányuló kérelem, hogy a nemzetközi lajstromozás hatálya kiterjedjen valamely Szerződő Fél területére; az ilyen megjelölésen a nemzetközi lajstromba történő bejegyzést is érteni kell;

(xix) megjelölt Szerződő Fél, illetve megjelölt hivatal: az a Szerződő Fél, illetve annak a Szerződő Félnek a hivatala, amelyet megjelöltek;

(xx) 1934. évi szöveg: a Hágai Megállapodás 1934. június 2-án, Londonban aláírt szövege (2004. évi XC. Törvény az ipari minták nemzetközi letétbe helyezéséről szóló 1925. évi Hágai Megállapodás 1999. július 2-án, Genfben felülvizsgált szövegének kihirdetéséröl).

Eltérő rendelkezés hiányában, ahol jogszabály

-munkaviszonyt említ, ott közszolgálati jogviszonyt,

-munkáltatót, ott közigazgatási szervet,

-munkavállalót, ott közszolgálati jogviszonyban állót,

-munkaszerződést, ott kinevezést,

-munkáltatói rendes felmondást, ott felmentést,

-munkaügyi vitát, ott közszolgálati jogvitát,

-munkabért vagy távolléti díjat, ott illetményt,

-hátrányos jogkövetkezménnyel járó intézkedést, ott fegyelmi eljárást

is érteni kell (1992. évi XXIII. törvény a köztisztviselők jogállásáról).

2) non-parity definitions [definicje nierównościowe]

(i) iconographic definitions [definicje ikonograficzne]

This type of definitions are usually found in appendixes. A definiendum is usually a picture (graphic representation of something) the meaning of which is given in the definiens, which in turn is verbalized. Such definitions may be found in the Road Code where the pictures of road signs are matched with their definitions.

(ii) conditional definitions [definicje warunkowe]

The most commonly used expressions in this type of definitions are gathered in table 10 below.

Table 10: The most often used linking words and expressions in conditional definitions

\begin{tabular}{|l|l|l|}
\hline \multicolumn{1}{|c|}{ POLISH } & \multicolumn{1}{c|}{ ENGLISH } & hUNGARIAN \\
\hline$\ldots$ o ile... & $\ldots$ if . . & \\
...o ile nie... & $\ldots$.unless... \\
...jeśli... & ...when... & \\
\hline
\end{tabular}

\section{Example in Polish:}

Art. 53. § 1. Pożytkami naturalnymi rzeczy są jej płody i inne odłączone od niej części składowe,

o ile według zasad prawidłowej gospodarki stanowią normalny dochód z rzeczy (KC). 


\section{Example in English:}

Art. 523. Good faith; definition.

An acquirere of a corporeal movable is in good faith for purpose of this Chapter unless he knows, or should have known, that the transferor was not the owner (LCC).

\section{Example in Hungarian:}

h) Fogyasztói érdekek képviseletét ellátó társadalmi szervezet: magánszemélyek által az egyesülési jogról szóló 1989. évi II. törvény alapján létrehozott társadalmi szervezet, illetve ezek szövetsége, ha az alapszabályban meghatározott célja a fogyasztók érdekeinek védelme, e célnak megfelelően legalább két éve müködik, és magánszemély tagjainak száma legalább ötven fö (1997. évi CLV. törvény a fogyasztóvédelemröl).

Ha a gyártó székhelye nem a Magyar Köztársaság területén van, az áru importálója minősül gyártónak (1997. évi CLV. törvény a fogyasztóvédelemről).

\section{Concluding Remarks}

The types of definitions are the same in Polish, English and Hungarian statutory instruments. However, the variety of expressions used to form them differs. There are more expressions used in Polish than in English, as a rule. What draws attention in Hungarian is the existance of nominal sentences without an auxiliary verb (van). It should be pointed out that the most often used linking word in Polish, that is ...jest... (or ...sq...), is considered incorrect by legal doctrine (Wronkowska, Zieliński 2002:). The linking expression which is rarely used but which is suggested as better (or even the only one which is correct) is ...jest to..., ...sq to... Furthermore, it is usually strongly advised to place the definiendum between quotation marks which is not always done by the legislator. The most typical expressions and words used in definitions are not translated here as the authors think it more proper to use dynamic equivalents in this particular case (that is the words and expressions quoted as used in the same context in the second language).

The constraints on the meaning and scope of usage of definitions which depend on the place in the statute in which the definition is found have not yet been discussed as it is assumed that translators do not change the order of sections while translating a statutory instrument and therefore such a detailed analysis of definition interpretation is seldom of much importance from the translators' perspective. However, it is very important from the lawyers' point of view. 


\section{Bibliography}

Apresjan, J. D. 1972. Definiowanie znaczeń leksykalnych jako zagadnienie semantyki teoretycznej. [in:] red. A. Wierzbicka, Semantyka i stowniki, Wrocław s. 39-57.

Benkő, L., Samu Imre, 1972. The Hungarian Language. Budapest: Akadémiai Kiadó.

Doroszewski, W. 1954. Z zagadnień leksykografii polskiej. Warszawa : PIW.

Doroszewski, W. 1970. Elementy leksykologii i semiotyki. Warszawa : PWN.

Mikołajczyk-Matyja, Nawoja, 1998. Definiowanie pojęć przez przeciętnych użytkowników języka i leksykografów. Poznań: Sorus.

Patryas, W. 1997. Definiowanie pojęć prawnych. Poznań: Wydawnictwo Naukowe UAM.

Seretny, Anna, 1998. Definicje i definiowanie. Kraków: Nomos.

Wronkowska, S., Zieliński M. 1993. Problemy $i$ zasady redagowania tekstów prawnych. Warszawa: Urząd Rady Ministrów.

Wronkowska, S., Zieliński, M. 1997. Zasady techniki prawodawczej. Warszawa: Wydawnictwo Sejmowe.

Zieliński, M. 2002. Wykładnia prawa. Zasady. Reguły. Wskazówki. Warszawa: Wydawnictwo Prawnicze LexisNexis.

\section{STATUTORY INSTRUMENTS:}

Insolvency Act 1986 (Great Britain).

Louisiana Civil Code (LCC).

US Code Construction Act Chapter 311.

Rozporządzenie Prezesa Ministrów w sprawie zasad techniki prawodawczej z dnia 20 lipca 2002r.

Uchwała no. 147 Rady Ministrów z dnia 5 listopada 1991 r w sprawie techniki prawodawczej.

Ustawa z dnia 15 września 2000 - Kodeks spółek handlowych (KH).

Ustawa z dnia 23 kwietnia 1964 r. - Kodeks cywilny (KC).

Ustawa z dnia 28 lutego 2003 r. - Prawo upadłościowe i naprawcze (PUIN).

Ustawa z dnia 6 czerwca 1997 r. - Kodeks karny (KK).

1/1975. (II. 5.) KPM-BM rendelet a közúti közlekedés szabályairól

1979. évi 5. törvényerejű rendelet a Büntető Törvénykönyvről szóló 1978. évi IV. törvény hatálybalépéséröl és végrehajtásáról

1992. évi XXII. törvény a Munka Törvénykönyvéröl

1992. évi XXIII. törvény a köztisztviselők jogállásáról

1992. évi XXIII. törvény a köztisztviselök jogállásáról

1995. évi LXVI. törvény a közokiratokról, a közlevéltárakról és a magánlevéltári anyag védelméről

1995. évi XL. törvény a közbeszerzésekről

1999. évi LX. Törvény a közbeszerzésekről szóló 1995. évi XL. törvény módosításáról

2000. évi C.törvény a számvitelröl

2001. évi CI. Törvény a felnőttképzésröl

2004. évi XC. Törvény az ipari minták nemzetközi letétbe helyezéséről szóló 1925. évi Hágai Megállapodás 1999. július

2-án, Genfben felülvizsgált szövegének kihirdetéséről

2006. évi V. törvény a cégnyilvánosságról, a bírósági cégeljárásról és a végelszámolásról 